\title{
The Use of Tungsten as a Chronically Implanted Material
}

\author{
Shah Idil, A. ${ }^{*}, \&$ Donaldson, N. ${ }^{1}$ \\ 1. Implanted Devices Group, Department of Medical Physics and Biomedical Engineering, University College London, UK.
}

\begin{abstract}
This review paper shows that tungsten should not generally by used as a chronically implanted material.

The metal has a long implant history, from neuroscience, vascular medicine, radiography, orthopaedics, prosthodontics, and various other fields, primarily as a result of its high density, radiopacity, tensile strength and yield point. However a crucial material criterion for chronically implanted metals is their long term resistance to corrosion in body fluids, either by inherently noble metallic surfaces, or by protective passivation layers of metal oxide. The latter is often assumed for elemental tungsten, with references to its "inertness" and "stability" common in the literature. This review argues that in the body metallic tungsten fails this criterion, and will eventual dissolve into the soluble hexavalent form $\mathrm{W}^{6+}$, typically represented by the orthotungstate $\mathrm{WO}_{4}{ }^{2-}$ (monomeric tungstate) anion. This paper outlines the metal's unfavourable corrosion thermodynamics in the human physiological environment, the chemical pathways to either metallic or metal oxide dissolution, the rate limiting steps and corrosion accelerating effects of reactive oxidising species the immune system produces post-implantation.

Multiple examples of implant corrosion have been reported, with failure by dissolution to varying extents up to total loss, with associated emission of tungstate ions and elevated blood serum levels measured. The possible toxicity of these corrosion products is also explored.

As the field of medical implants grows and designers explore novel solutions to medical implant problems, the authors recommend the use of alternative materials.
\end{abstract}

Keywords: $\quad$ tungsten, medical devices, implants, corrosion, chronic

\footnotetext{
*a.shahidil@ucl.ac.uk
} 


\section{Tungsten - An Overview}

Tungsten (W, atomic number 74), as a result of its unique material characteristics, has long been used to make medical implants. It belongs to the refractory group of metals, those known for their extraordinary resistance to heat and wear $[1,2]$. It has the highest melting point of all the metals $\left(3422^{\circ} \mathrm{C}\right)[3]$ and the lowest vapour pressure. It has very high tensile strength [4] and is a hard, tough material that resists buckling forces at small dimensions. It is one of the densest of the naturally occurring elements, at $19.25 \mathrm{~g} / \mathrm{cm}^{3}$ (surpassed only by U, Re, Pt, Ir, and Os) [3, 5]. W has the largest cohesive energy of all the elements, including diamond (carbon): 7.9-10.09eV/atom depending on the theoretical approach [6]. The only stable crystallographic form is $\alpha-\mathrm{W}$, with a body-centred cubic lattice structure [5]. These physical characteristics originate from the nature of tungsten's metallic bonding, with strong unsaturated covalent bonds between the valence $5 \mathrm{~d}$ orbitals [3]. The interested may pursue tungsten's physical and chemical properties further in reference texts: Lassner \& Schubert's [3] or Gmelin's Atlas [7].

From a biological perspective, $\mathrm{W}$ plays a role only in bio-molecules in niche ecologies, as metal sites bound by protein-derived ligands in tungsto-enzymes in hyperthermophilic archaea [8, 9] usually in cognates to molybdenum [10]. These extremophiles are termed "obligate anaerobes" and their tungsto-enzymes catalyse redox reactions involving carboxylic group to aldehyde group conversions

[3]. There are no other reported instances of $\mathrm{W}$ bio-molecules and no reported functions of $\mathrm{W}$ in human biology.

\section{Corrosion}

Corrosion behaviour of a metal cannot be divorced from the very specific environmental conditions in which it will be expected to operate. It is the interplay of metal and environment that determines the thermodynamics, kinetics and pathways of the corrosion process [11]. The operating environment of medical implants can be modelled as wet, chloride-rich saline with reactive highly oxidising species present due to the inflammation response $[12,13]$. The $\mathrm{pH}$ is typically 7.4 , but may vary from 5.6 post-surgery to 9.0 during infection $[14,15]$. The effects of various other environmental factors such as proteins, lipids, and ions should also be considered.

W has often been referred to as having "excellent corrosion resistance" [3] and in some biomaterials literature as "inert" and "stable" [16, 17] in aqueous solutions [18]. However, in the presence of water, at $25^{\circ} \mathrm{C}$ under $1 \mathrm{~atm}$ pressure, metallic $\mathrm{W}$ is not thermodynamically stable [14, 19, 20]. In neutral aqueous solutions a native $\mathrm{WO}_{3}$ metal oxide film forms but continually dissolves away, and is thus non-passivating [3].

\subsection{Corrosion Thermodynamics and Pourbaix Diagrams}

The electrochemical behaviour of $\mathrm{W}$ has a complicated $\mathrm{pH}$ dependence. Some authors have divided its electrochemical behaviour into 5 distinct $\mathrm{pH}$ regimes with different reaction mechanisms, few of which are relevant to the implant designer [21].

$\mathrm{W}$ forms a stable oxide layer of $\mathrm{WO}_{3}$ in acidic solutions $(\mathrm{pH}<4)[22-31]$ - this is well known, technologically significant in other fields but well outside the operating $\mathrm{pH}$ range of typical medical implants (except gastric implants). 
In solutions of neutral and alkaline $\mathrm{pH}$ values, the $\mathrm{W}_{\mathrm{x}} \mathrm{O}_{\mathrm{y}}$ surface species form soluble tungstate ions (often represented as "orthotungstate" $\mathrm{WO}_{4}{ }^{2-}$ [32]) which results in the continual dissolution of surface material; these are the products of $\mathrm{W}$-oxide dissolution as well as active $\mathrm{W}$ metal dissolution at higher $\mathrm{pHs}[23,33-35]$. All authors agree that in neutral-to-alkaline aqueous environments, the oxide phase on the metal surface hydrates, and then passes into solution as these hexavalent tungstate ions [18, 33, 34, 36-42]. Weidman's chronoamperometry measurements at 1.0V sweeping from $\mathrm{pH} 0.5$ to 13.0 presented sharp increases in current densities between $\mathrm{pH}$ 4-6 indicating there is no passivation occurring via oxidation at higher $\mathrm{pH}$ values [22]. Heumann \& Stolica used weight loss measurements and coulometric methods to determine that the valence of dissolved $\mathrm{W}$ was indeed 6.0 [36] agreeing with earlier work regarding W solubility.

According to Pourbaix, the borderline conditions of corrosion/passivation occur between $\mathrm{pH}$ 4-6 (Figure 1). Above $\mathrm{pH} \mathrm{6,} \mathrm{general} \mathrm{corrosion} \mathrm{will} \mathrm{occur,} \mathrm{with} \mathrm{hydrogen} \mathrm{evolution} \mathrm{in} \mathrm{the} \mathrm{absence} \mathrm{of}$ oxidising species, and without hydrogen evolution in their presence. The tendency for corrosion rises with increasing potential [19] as may occur when W is used as stimulating electrodes. Weidman reports that at current densities exceeding $0.1 \mathrm{mAcm}^{-2}$ there is a breakdown in the passivated surface regardless of $\mathrm{pH}$, even in acidic zones [22] - a possible alteration to Pourbaix's initial diagram. This acid-soluble $\mathrm{WO}_{2}{ }^{2-}$ ion has been proposed by others $[43,44]$.

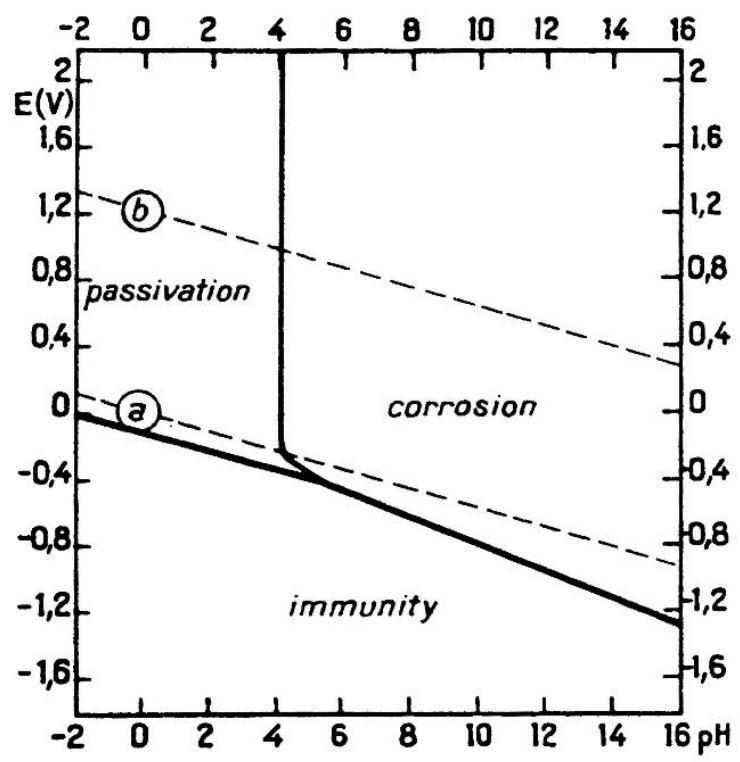

Figure 1 - Pourbaix's theoretical $\mathrm{E}_{\mathrm{H}} / \mathrm{pH}$ diagram for $\mathrm{W}$ in $\mathrm{H}_{2} \mathrm{O}$ at $25^{\circ} \mathrm{C}$ [20]

The original Pourbaix diagram applies to pure water at $25^{\circ} \mathrm{C}$, not the physiological environment, so should be used with caution. His analysis also ignores the numerous complexes $\mathrm{W}$ forms - these include hydrochloric complexes of trivalent $\mathrm{W}$, hydrofluoric and oxalic complexes of tetravalent $\mathrm{W}$ and cyanide complexes of pentavalent W. Some tungstates of alkali metals are soluble, others are $\operatorname{not}[45]$.

A useful improvement to the diagram was generated computationally by Patrick for W in PBS using the CorrosionAnalyzer 1.3 software - approximately 60 solid, aqueous and gaseous species were considered [13]. It is redrawn here for clarity with dominant species labelled (Figure 2). Similar conclusions can be made; $\mathrm{W}$ is clearly a base metal, with a stable domain in the physiological $\mathrm{pH}$ range (x-y) (5.6 to $9.0[14])$ only outside of the water window (a-b). 


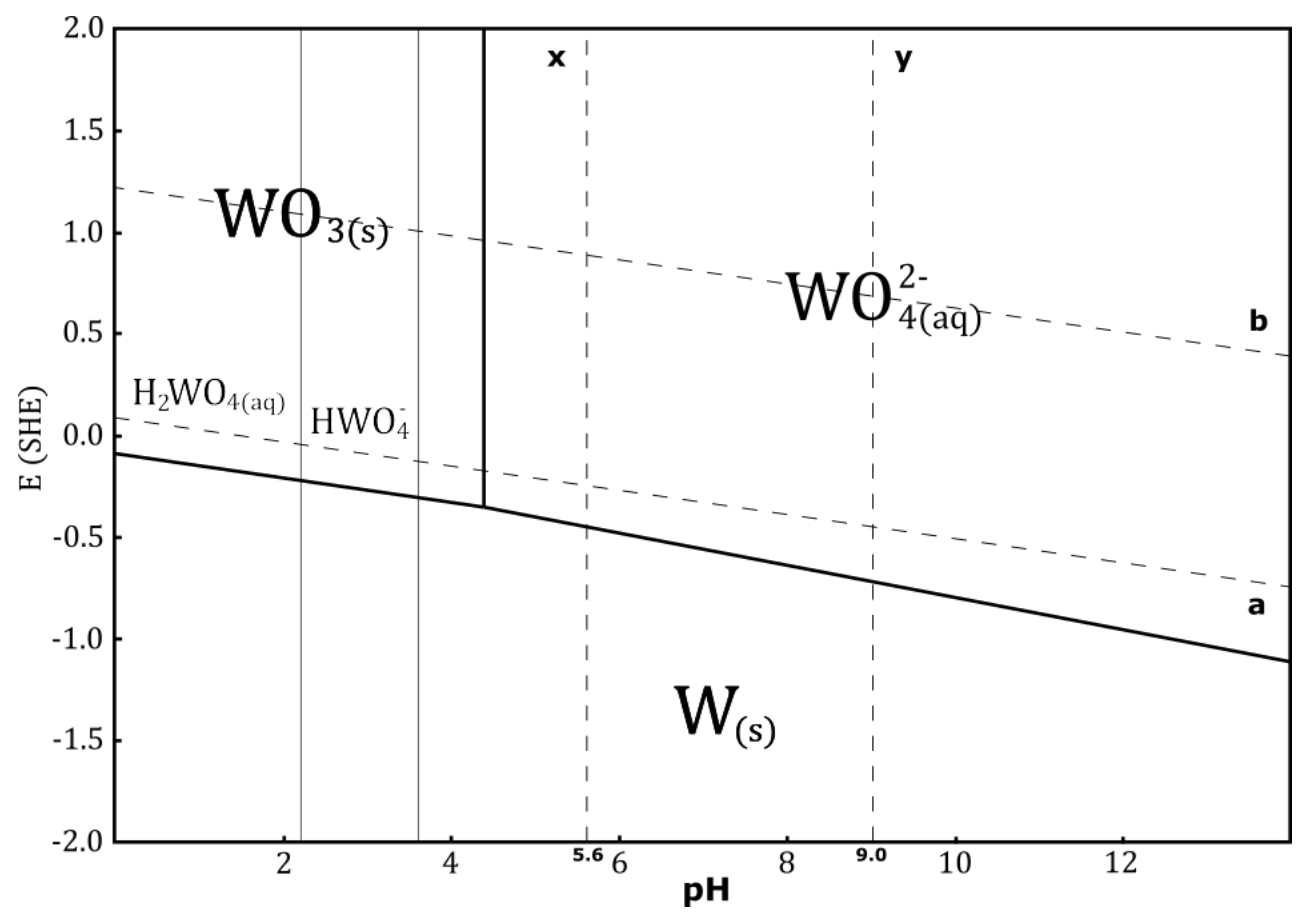

Figure $2-\mathrm{E}_{\mathrm{H}} / \mathrm{pH}$ Diagram for $\mathrm{W}$ in PBS based on Patrick [13]

Heumann and Stolica and others still do refer to tungsten's "protective film" of $\mathrm{WO}_{2}$ [18] - what may be termed a protective or passive oxide film may continually form at all $\mathrm{pH}$ values, inhibiting dissolution to some degree [46]. However, the long term behaviour remains continual dissolution into soluble hexavalent $\mathrm{W}^{6+}$. With this continual dissolution process in neutral solutions $\mathrm{W}$ is unsuitable for use as a chronic implant material.

\subsection{Rates of Corrosion}

Lassner and Schubert report corrosion of metallic $\mathrm{W}$ at the rate of $3.8 \mu \mathrm{gm}^{-2} \mathrm{~h}^{-1}$ at $38^{\circ} \mathrm{C}$ in distilled water [3]. Gmelin reports corrosion rates of $0.83 \mu \mathrm{gm}^{-2} \mathrm{~h}^{-1}$ in $3 \% \mathrm{NaCl}$ solutions and $89.2 \mu \mathrm{gm}^{-2} \mathrm{~h}^{-1}$ in $10 \% \mathrm{KOH}$ solutions, both at $20^{\circ} \mathrm{C}$ aerated and agitated $[5,7]$. Of more significance, $\mathrm{W}$ exhibits a corrosive weakness to hydrogen peroxide [46]. Peroxide solutions dissolve $\mathrm{W}$ without inhibition and the rate of dissolution increases linearly with $\mathrm{H}_{2} \mathrm{O}_{2}$ concentration [7, 47]. Hydrogen peroxide etches W along crystal planes (100), (111) and (112) and further at subgrains, and wide angle boundaries. It rapidly dissolves powders [3], as well as bulk billets of compact $\mathrm{W}$, with dissolution rates of $1.6 \mathrm{mgL}^{-}$ ${ }^{1} \mathrm{~min}^{-1}$ reported in aqueous solutions of peroxide at a concentration of $14 \mathrm{~g} \mathrm{H}_{2} \mathrm{O}_{2} / \mathrm{L}$ over $180 \mathrm{~min}$ at $20 \pm 1{ }^{0} \mathrm{C}$ [48]. This peroxide effect has also been noted by Patrick et al. in a study on W microelectrodes where an increase in corrosion rates on the range of 2 orders of magnitude in benchtop studies with $30 \mathrm{mM} \mathrm{H}_{2} \mathrm{O}_{2}$ in PBS vs no peroxide was reported [13].

While the relation between these experimental concentrations and physiological concentrations is debatable, it is worth mentioning given that peroxide is readily produced in the body's foreign-body immune response near implants. In addition to peroxides, reactive oxygen species such as the superoxide anion and the hydroxyl radical are rapidly released by immune cells including microglia in the CNS [13, 49] and neutrophils in the blood [50] in events termed "oxidative bursts" [51-53]. In non-acute animal studies, Prasad reports the presence of activated microglia near W electrode tracks in all cases, indicating neuroimflammatory response regardless of post-implantation survival times 
and electrode performance [54]. These species would no doubt accelerate the corrosion of W through the oxidation to its soluble hexavalent form.

\section{Chemical Reactions}

The overall 6 electron stoichiometric equation for neutral to basic solutions is [20, 34]:

$$
\mathrm{W}+4 \mathrm{H}_{2} \mathrm{O} \rightarrow \mathrm{WO}_{4}{ }^{2-}{ }_{(\mathrm{aq})}+8 \mathrm{H}^{+}+6 \mathrm{e}^{-}
$$

This overall anodic equation occurs step-wise as below, elucidating the rate-determining step which is first-order with respect to $\mathrm{OH}^{-}[3]$ :

$$
\begin{aligned}
& \mathrm{W}_{(\mathrm{s})}+2 \mathrm{OH}^{-} \rightarrow \mathrm{WO}_{(\mathrm{s})}^{+}+3 \mathrm{e}^{-}+\mathrm{H}_{2} \mathrm{O} \\
& \mathrm{WO}_{(\mathrm{s})}^{+}+2 \mathrm{OH}^{-} \rightarrow \mathrm{WO}_{2(\mathrm{~s})}+\mathrm{e}^{-}+\mathrm{H}_{2} \mathrm{O} \\
& \mathrm{WO}_{2(\mathrm{~s})}+\mathrm{OH}^{-} \rightarrow \mathrm{WO}_{3} \mathrm{H}_{(\mathrm{s})}+\mathrm{e}^{-} \\
& \mathrm{WO}_{3} \mathrm{H}_{(\mathrm{s})}+\mathrm{OH}^{-} \rightarrow \mathrm{WO}_{3(\mathrm{~s})}+\mathrm{e}^{-}+\mathrm{H}_{2} \mathrm{O} \quad \text { (rate determining step) } \\
& \mathrm{WO}_{3(\mathrm{~s})}+\mathrm{OH}^{-} \rightarrow \mathrm{HWO}_{4}^{-}{ }_{(\mathrm{aq})} \\
& \mathrm{HWO}_{4}^{-}\left(\text {(aq) } \rightarrow \mathrm{WO}_{4}^{2-}{ }_{(\mathrm{aq})}+\mathrm{H}_{2} \mathrm{O}\right.
\end{aligned}
$$

The reduction of water/oxygen and of peroxide are the likely in-vivo cathodic reactions [13]:

$$
\begin{aligned}
& \mathrm{O}_{2}+2 \mathrm{H}_{2} \mathrm{O}+4 \mathrm{e}^{-} \rightarrow 4 \mathrm{OH}^{-} \\
& \mathrm{H}_{2} \mathrm{O}_{2}+2 \mathrm{H}^{+}+2 \mathrm{e}^{-} \rightarrow 2 \mathrm{H}_{2} \mathrm{O}
\end{aligned}
$$

Alternative anodic pathways are reported [22]. Older publications state $\mathrm{W}_{2} \mathrm{O}_{5} \mathrm{OH}_{(\mathrm{s})}+\mathrm{W}_{2} \mathrm{O}_{5(\mathrm{~s})} \rightarrow$ $\mathrm{W}_{2} \mathrm{O}_{5}-\mathrm{OH}-\mathrm{W}_{2} \mathrm{O}_{5(\mathrm{~s})}$ as the rate determining step [33] but this was superseded by newer data consonant with reaction (3) followed by rapid the $\mathrm{OH}^{-}$ion-assisted dissolution of $\mathrm{WO}_{3} \mathrm{H}_{(\mathrm{s})}$ to the $\mathrm{WO}_{4}{ }^{2-}$ (aq) species [46]. Works quoted by Gmelin state that the $\mathrm{W}_{2} \mathrm{O}_{5}$ referred to in older literature does not exist and corresponds in fact to $\mathrm{W}_{20} \mathrm{O}_{58}$ (or $\mathrm{WO}_{2.9}$ ) [19] and this is supported by more recent literature. The above series of equations thus corresponds to the oxidative series of $\mathrm{W}: \mathrm{W} \rightarrow \mathrm{W}^{3+} \rightarrow \mathrm{W}^{4+} \rightarrow \mathrm{W}^{5+} \rightarrow$ $\mathrm{W}^{6+}$.

As a point of interest anodic polarisation of $\mathrm{W}$ in acidic media (or reduction from $\mathrm{WO}_{3}$ ) will present distinct stages through the formation of all the stable stoichiometric oxides, each with a distinct colour regime:

$\mathrm{W}$ (grey) $\rightarrow \mathrm{WO}_{2}$ (brown) $\rightarrow \mathrm{W}_{18} \mathrm{O}_{49}$ (violet) $\rightarrow \mathrm{W}_{20} \mathrm{O}_{58}$ (blue) $\rightarrow \mathrm{WO}_{3}$ (yellow) [3]

Given tungsten's particular weakness to peroxide dissolution, this chemical reaction pathway will be mentioned:

$$
\mathrm{W}_{(\mathrm{s})}+2 \mathrm{H}_{2} \mathrm{O}_{2(\mathrm{aq})} \rightarrow \mathrm{WO}_{2(\mathrm{~s})}+2 \mathrm{H}_{2} \mathrm{O}
$$

Two pathways have then been proposed, resulting in various compounds referred to as peroxotungstates, pertungstates or pertungstic acid [3]:

$$
\begin{aligned}
& \mathrm{WO}_{2(\mathrm{~s})}+2 \mathrm{H}_{2} \mathrm{O}_{2(\mathrm{aq})} \rightarrow \mathrm{H}_{2} \mathrm{WO}_{4} \\
& \mathrm{H}_{2} \mathrm{WO}_{4}+2 \mathrm{H}_{2} \mathrm{O}_{2(\mathrm{aq})} \rightarrow \mathrm{H}_{2} \mathrm{~W}_{3} \mathrm{O}_{12}+4 \mathrm{H}_{2} \mathrm{O}
\end{aligned}
$$

and; 


$$
\begin{aligned}
& 2 \mathrm{WO}_{2(\mathrm{~s})}+6 \mathrm{H}_{2} \mathrm{O}_{2(\mathrm{aq})} \rightarrow \mathrm{H}_{2} \mathrm{~W}_{2} \mathrm{O}_{11}+5 \mathrm{H}_{2} \mathrm{O} \\
& 3 \mathrm{H}_{2} \mathrm{~W}_{2} \mathrm{O}_{11} \rightarrow 2 \mathrm{H}_{2} \mathrm{~W}_{3} \mathrm{O}_{12}+\mathrm{H}_{2} \mathrm{O}
\end{aligned}
$$

Pourbaix represents these reaction products as $\mathrm{WO}_{5}{ }^{2-}$ ions; this is an uncommon usage [20].

\subsection{Electrochemistry}

The open-circuit (or $\mathrm{E}_{\text {corr }}$ corrosion potential) of $\mathrm{W}$ was found to be approximately $-100 \mathrm{mV}$ at $\mathrm{pH} 7$ with respect to the standard hydrogen electrode [42] and decreases by $43 \mathrm{mV}$ per $\mathrm{pH}$ increase [18]; as the $\mathrm{pH}$ increases, the corrosion potential shifts to less noble potentials [23, 46]. In these studies the anions of the buffer solutions $\left(\mathrm{CO}_{3}{ }^{2-}, \mathrm{HCO}_{3}{ }^{-}, \mathrm{PO}_{4}{ }^{3-}\right.$, etc.) were found to influence the electrochemistry. Kelsey found the anodic Tafel slope at all concentrations of hydroxide to be $0.14 \mathrm{~V} /$ decade [34].

Readers with deeper interest in the electrochemical behaviour of $\mathrm{W}$ electrodes at anodic potentials, at wider $\mathrm{pH}$ ranges, and with results from cyclic voltammetry, linear sweep voltammetry, potentiodynamic polarization experiments and analyses of the AC impedance spectra of W-oxide films should consult the excellent papers by El-Wakkad [42], El-Basiouny [39, 42, 43, 55], Heumann $\&$ Stolica [18, 36], Wiedman [22] and Anik et al. [21, 23, 30, 56, 57], amongst others.

\section{Medical Implant Corrosion}

Instances of corrosion of $\mathrm{W}$ medical implants in the literature are summarised here. Examples are primarily of embolisation coils and neural microelectrode probes. Implant functionality depends on the integrity of the bulk metal form; the abiotic failure of medical implants via metallic corrosion inhibits their chronic use.

\subsection{Corrosion of Tungsten Coils}

Tungsten coils have been used to perform transcatheter embolisations of pathological blood vessels due to their high radiopacity (W behaving as a very effective X-ray absorber due to its high density [3]) as well as its thrombogenicity [58, 59]. The W MDS "Mechanically Detachable System" coils (Balt Extrusion, Montmorency, France) are an example of a once commonly used system [16, 60-62].

Rabbit studies of W coils implanted for 3-6 months for embolisation exhibited corrosion, with black particles of metal spectroscopically determined to contain W \& Fe found in the adventitia of the aneurysm and outside the lumen, distant from the $\mathrm{W}$ coils in phagocytic cells and also in fibroblasts and spindle cells [63]. The iron is hypothesised by Peuster to be not from coil manufacturing contamination but agglutinated blood on explantation [62]. A similar rabbit study by Peuster et al. demonstrated 3.5-fold increase in serum $\mathrm{W}$ concentration as early as $15 \mathrm{~min}$ post-implantation [64].

In 1998, the study by Weill et al. first presented the "disturbing" finding of in-vivo W corrosion in 5 patients with decreasing levels of radiopacity in skull plain x-ray films of MDS embolisation spirals 33-45 months post-implantation for intracranial aneurysm or dural fistula by venous approach. W blood serum levels in patients were 10-50 times the population baseline, proportional to length of coil implanted [16]. Additionally elevated blood serum levels in one patient 3 months post-implantation $(4.95 \mu \mathrm{g} / \mathrm{L}$ vs baseline $<0.1 \mu \mathrm{g} / \mathrm{L}$ from pooled population samples $[16,65])$ without a demonstrably noticeable decrease in radiopacity indicates corrosion occurs earlier than is radiographically detectable. 
Barrett et al. demonstrated similar results for W Mechanically Detachable System coils used for endovascular embolisation of varicoceles in the scrotum, presenting radiographic evidence of $\mathrm{W}$ resorption in 4/18 patients (Figure 3), and elevated W blood-levels in 18/19 patients (mean 40 months post-implantation) [66]. Bachthaler et al. reported $\mathrm{W}$ coil corrosion for intracerebral aneurysms and dural fistulae 26 months post-implantation in 9 of 14 patients also by plain radiography, with two patients displaying complete coil resorption. W blood levels were elevated in $6 / 14$ patients and urine levels were elevated in all [60]. Others have reported similar radiographic and blood serum results with the use of $\mathrm{W}$ embolisation coils in intracranial aneurysms, abdominal aortic stent grafts, spermatic vein varioceles, oesophageal and gastric varices and other pathological blood vessels (Figure 4 \& 5) [61, 67-70].

In a metallographic analysis Peuster's SEM examination of the $\mathrm{W}$ coils explanted from the rabbit subclavian arteries after 4 months demonstrated a clear change from a smooth surface of the control with uniformly circular cross-section to surface roughening, pitting and crevice corrosion in the implanted coils [64].

Various causes for this corrosion have been proposed in the literature: Weill et al. blame the metallic impurity of the MDS coils $[16,63]$. This was disproven by studies that spectroscopically verified the purity of the $\mathrm{W}$ pre-implantation ( $>99.9 \%$ by mass) $[60-62,71]$. Barrett et al. attribute degradation due to mechanical effects of percussive systolic-diastolic blood flow on the spirals [66] but this explanation was nullified when corrosion was observed by radiography in venous fistula drainage pathways with no percussive flow [16] as well as in cannulae of the spermatic vein [66]. Other cases have been reported [72].

While it may be possible that mechanical factors such as percussive flows may accelerate corrosion, as discussed at length previously, the underlying reason for $\mathrm{W}$ coil corrosion and eventual failure is known: i.e. the unfavourable thermodynamics of metal corrosion within the implant environment of the human body, i.e. the propensity for metallic $\mathrm{W}$ to dissolve into tungstate at $\mathrm{pH} 7.4$ and $37^{\circ} \mathrm{C}[19$, 20]. A mass dissolution rate of $29 \mu \mathrm{g} /$ day was reported for $\mathrm{W}$ coils [73] but the proper rate relation to exposed surface area is not explored. Peuster reports localised acidosis in occluded vessels due to metabolic processes and lack of oxygen carriers leading to stable passivating oxide layers on the $\mathrm{W}$ coil [74]. However, reports of coil dissolution refute this - evidence of local pH less than 4 (Pourbaix's upper limit for stable oxide formation) was not reported.

The general consensus of authors is that the use of $\mathrm{W}$ embolisation coils should cease $[16,60,61,63$, 66-69, 74]. Recanalization as the failure mode of these $\mathrm{W}$ embolisation coils occurred in $58.3 \%$ of cases in Kampmann [68] and was reported by others as proportional to degree of corrosion [16] - an unacceptable risk for patients. 


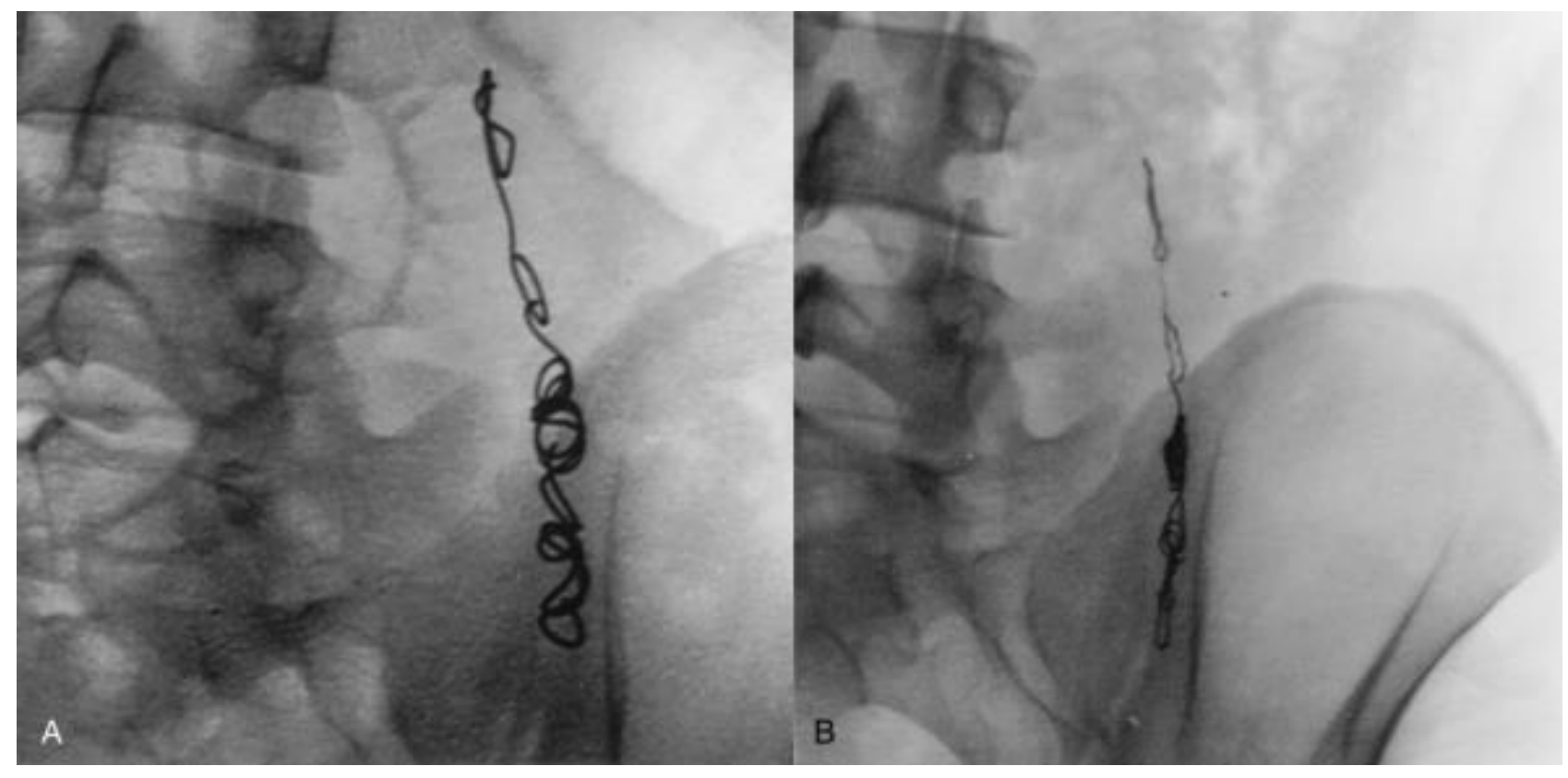

Figure 3 - Endovascular embolisation of varicoceles in the spermatic vein with W coils. A: Image obtained during procedure; B: 57 months later, with clear reduction in substance, thickness and overall volume of coil [66].

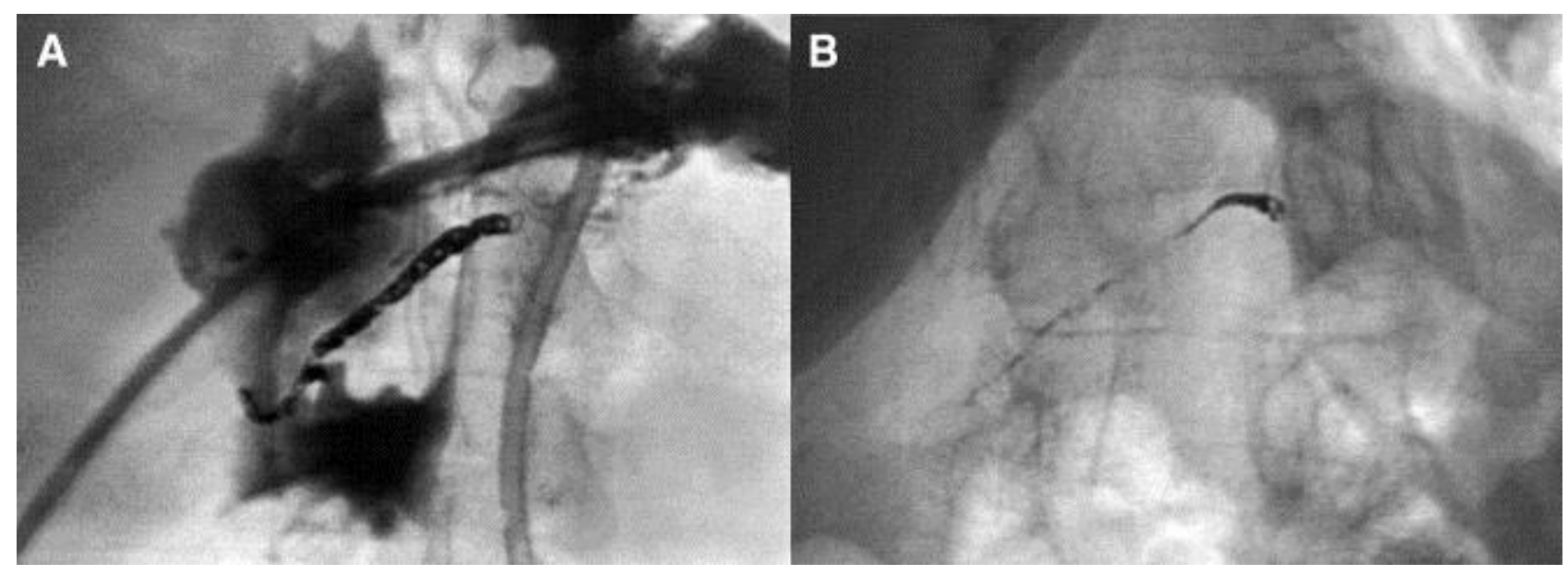

Figure 4 - W coil embolisation of the right hepatic artery for massive haemorrhage after stomach resection. A: Image obtained immediately post-procedure; B: 35 months later, with clear decrease in metal density [60].

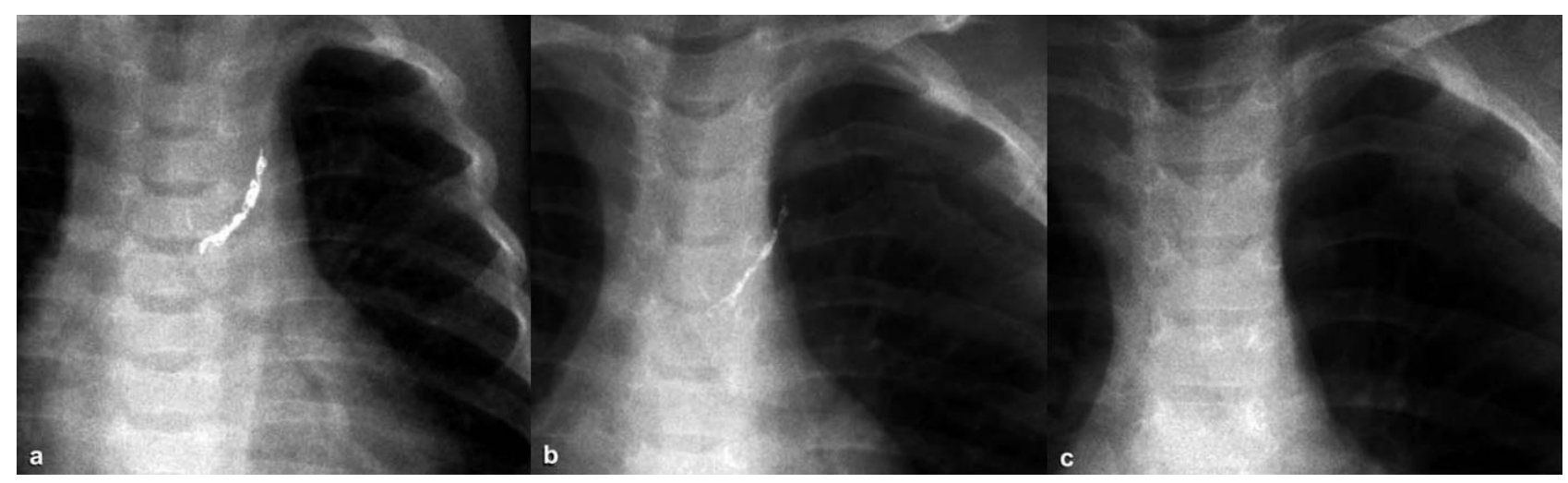

Figure 5 - Chest radiographs in a 3 month-old girl after surgical correction of multiple ventricular septal defects and coarctation repair. A: 1 day after coil embolisation of one aorto-pulmonary collateral with three 3.50-mm W coils; B: After 11 month; and C: After 28 months. All coils are completely corroded after 28 months [68]. 


\section{2. $\quad$ Corrosion of Tungsten Microwires}

Long-term corrosion resistance is a necessary condition for extracting stable signals from chronic implanted neural electrodes. Additionally, for single neuron recordings, electrodes must be less than $200 \mu \mathrm{m}$ from the soma to record the action potential [75] - at such microscopic scales, even the slightest corrosion will cause device failure.

W microwires have been used in animals for this purpose for almost 60 years [54, 76-79]. High-purity wire is readily available, and the metal is stiff and robust enough to be readily fabricated into fine tips capable of performing single neuron electrophysiological recordings [76]. Commercial W microwires of $99.95 \%$ purity are available at various diameters $(\sim 50-125 \mu \mathrm{m})$. These can be sharpened to tips of ultramicroscopic dimensions $(0.5-0.05 \mu \mathrm{m})$ by electrolytic etching, with oscillatory dipping into saturated $\mathrm{KNO}_{2}$ or other etching solution while passing a current [80-83]. Tungsten's high melting point and low coefficient of thermal expansion enable it to be easily encapsulated within glass capillaries [84] while other encapsulants such as polyimide [82, 85, 86] or Parylene-C have also been used. Exposed tips may be electroplated with gold, platinum or other metals to decrease the electrode impedance [84, 87].

With the same technology, W has also been used to form recording electrode arrays [85]. These are termed linear microelectrode arrays (LMA), microelectrode arrays (MEA), microwire arrays (MWA) or floating microelectrode arrays (FMA). There are many examples of recording sites in commercial and non-commercial research utilising intracortical microelectrode arrays of $\mathrm{W}$ microwires $[17,85$ 91]

Unfortunately, in chronic applications, corrosion is again a limiting factor for their success as implants. Prasad et al. note that while $\mathrm{W}$ microwires are able to initially provide stable recordings, they fail to do so for years, reporting roughening of the surfaces of their $50 \mu \mathrm{m}$ diameter microelectrodes 2 hours after implantation, recession and cavitation of the surfaces after two weeks to 16 days, and eventual cracking, pitting, hole-formation and deep recession of the electrodes into the insulation in months following (Figure 6) [54]. Williams reports $\mathrm{W}$ microwire electrodes of $35 \mu \mathrm{m}$ diameter (unsharpened) having viability of continuous recordings from guinea pig tests of only five weeks or less [85]. Sanchez et al. reported corrosion of $\mathrm{W}$ microwires after 4 weeks of in vivo implantation [87]. Others report similar degradation of recording surfaces of W microwires [87].

A very thorough analysis of this corrosion phenomenon was performed by Patrick et al. on commercial 50 $\mu$ m diameter W microwires (California Fine Wire) encased in epoxy (Epotek 302-3M) [13]. Reported bench-top corrosion rates were $300-700 \mu \mathrm{m} / \mathrm{yr}$ for pure $\mathrm{W}$ in $0.9 \% \mathrm{PBS}$, and $10,000-$ $20,000 \mu \mathrm{m} / \mathrm{yr}$ for Au-plated $\mathrm{W}$ (gold deposited circumferentially) in $0.9 \% \mathrm{PBS}+30 \mathrm{mM} \mathrm{H}_{2} \mathrm{O}_{2}$ (the latter to simulate the highly oxidative environment of post-implantation inflammation). Assuming $100 \% \mathrm{~W}$, ideal cylindrical geometry, full density and $\rho_{\mathrm{w}}=19.25 \mathrm{~g} / \mathrm{cm}^{3}$, this corresponds to 0.45 $1.1 \mu \mathrm{g} / \mathrm{yr}$ and $15-30 \mu \mathrm{g} / \mathrm{yr}$ respectively. No data on pure $\mathrm{W}$ in $\mathrm{PBS} / \mathrm{H}_{2} \mathrm{O}_{2}$ was offered.

Simultaneous in-vivo studies in adult male Sprague-Dawley rats implanted cranially with Au-plated $\mathrm{W}$ reported corrosion rates of $100 \mu \mathrm{m} / \mathrm{yr}(0.151 \mu \mathrm{g} / \mathrm{yr})$ with the difference hypothesised to be due to the formation of an oxygen-blocking biofilm [13]. 


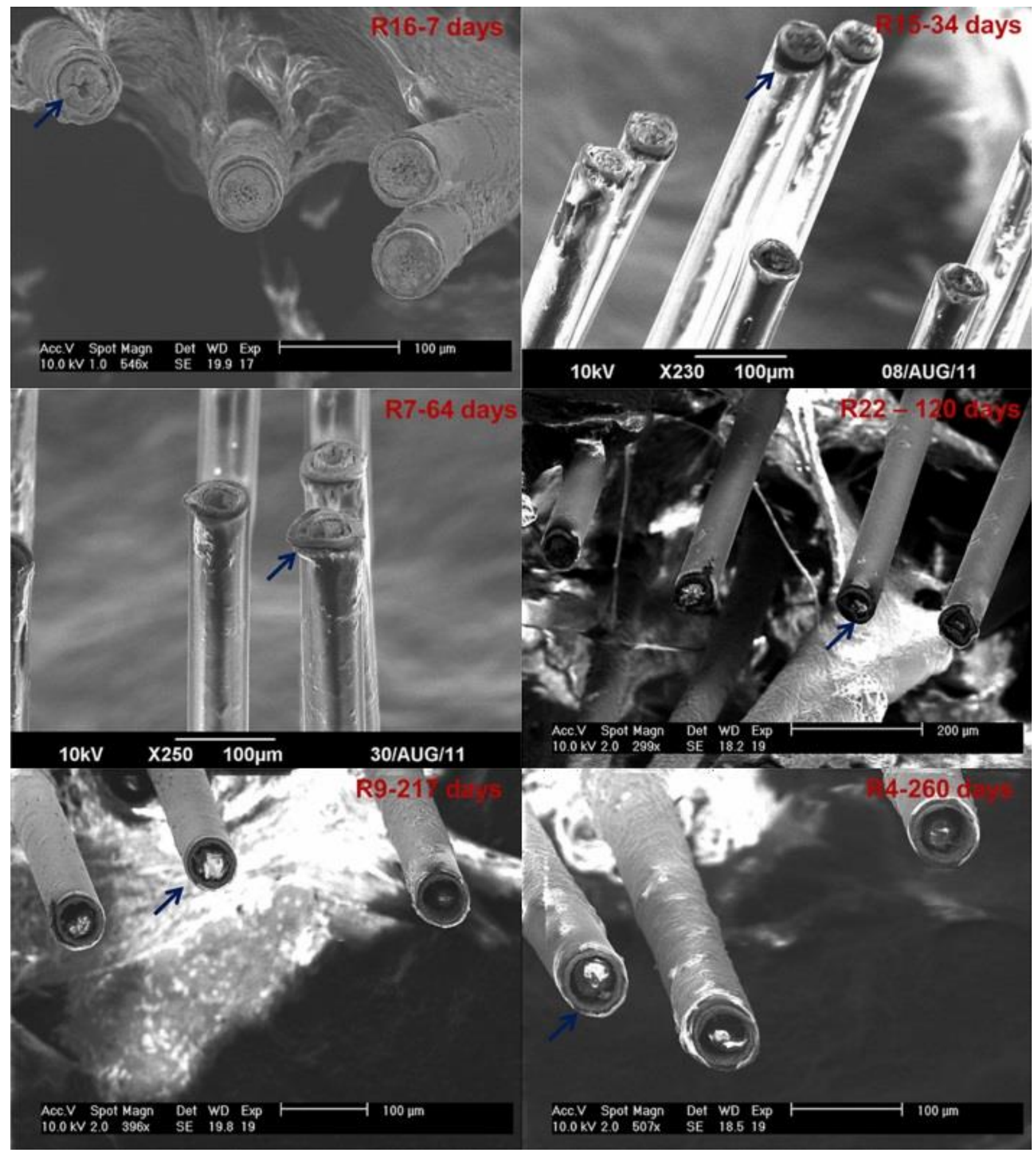

Figure 6 - Post-explantation SEM images of 16-channel tungsten microwire arrays with 50 $\mu$ m diameter electrodes coated with $10 \mu \mathrm{m}$ thick polyimide insulation. The images depict the progression of electrode recording site corrosion and deterioration for increasing implant durations in different rats labelled by "R" (R16: 7 days; R15: 34 days; R7: 64 days; R22: 122 days; R9: 217 days; R4: 260 days). The arrows (original authors' addition) indicate examples of polyimide delamination, and electrode recording site corrosion for individual electrodes [54]. 
From purely visual analysis, in the PBS-only samples, the electrode surfaces polished to $1 \mu \mathrm{m}$ smoothness displayed roughening after 1 day, pitting after 2 days, and full recession from initial surface after 6 days to a depth of $>4 \mu \mathrm{m}$, similar to the reports by Prasad. In the in-vivo studies, the $\mathrm{W}$ receded within its insulation $24 \pm 8 \mu \mathrm{m}$ after 87 days of implantation (Figure 7 ). No oxide layer was present in either case, contradicting claims of oxide passivation due to localised acidosis.

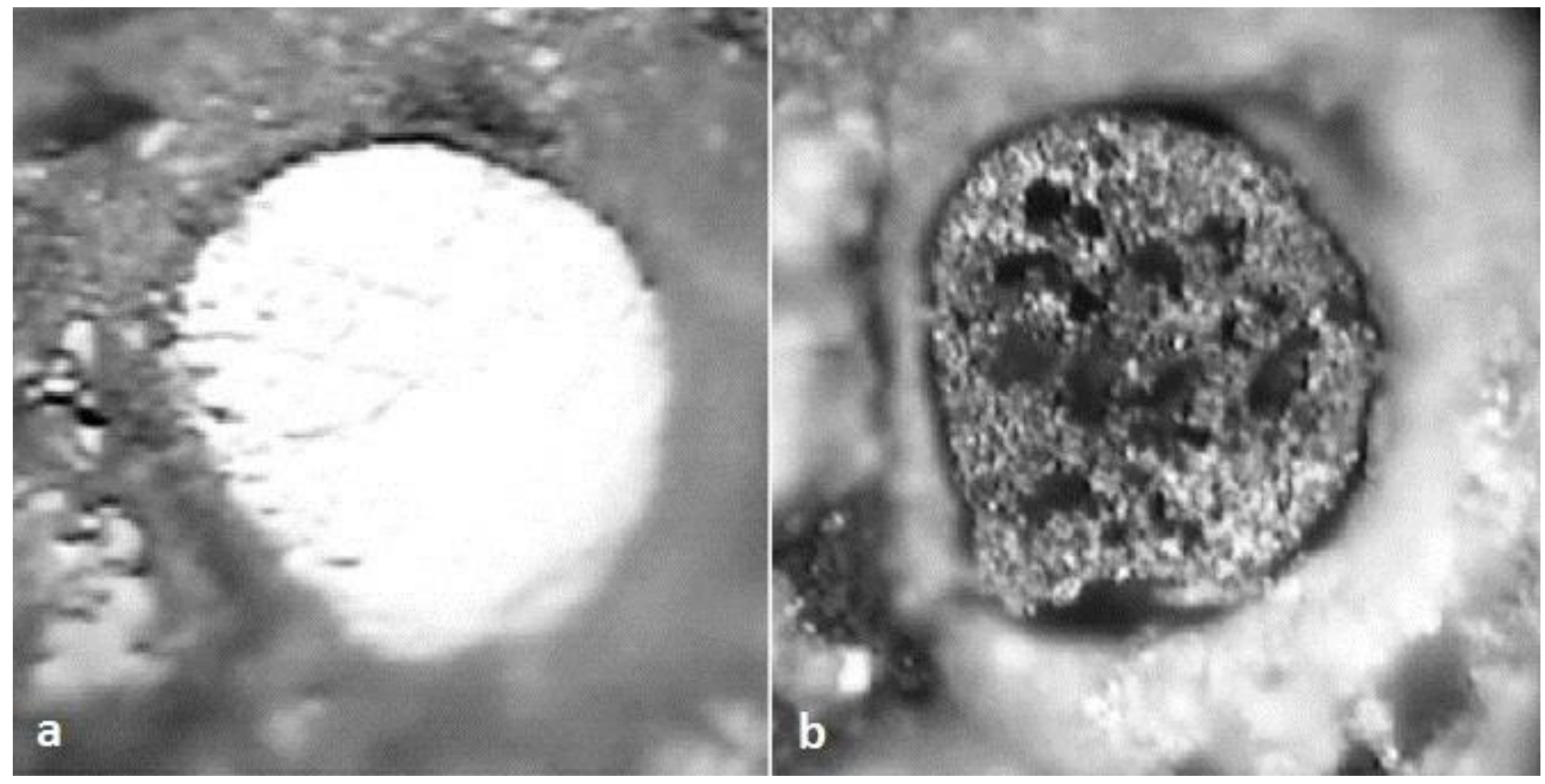

Figure 7 - Optical photographs of 50 $\mu$ m nominal diameter W electrode. A: Before immersion in PBS (polished); B: After 23 days of immersion, with evidence of corrosion: surface roughening, pitting, dark oxidic patches [13].

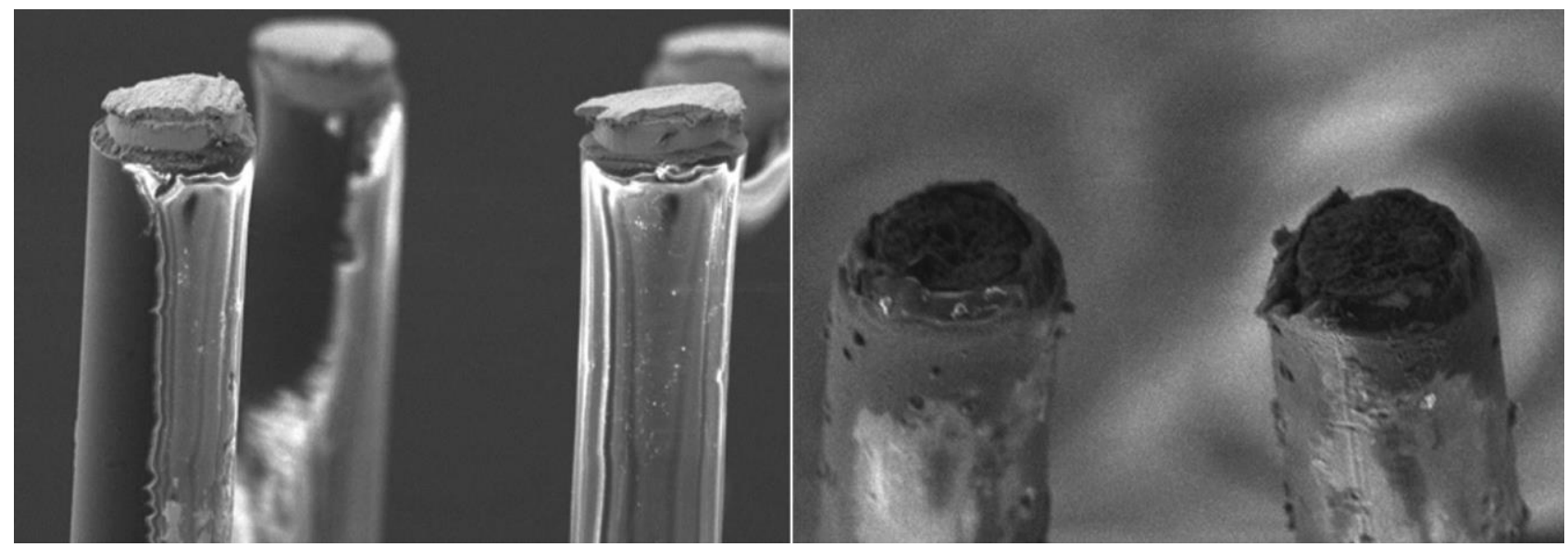

Figure 8-SEM images of recording tips of 50 $\mathrm{mm}$ diameter $\mathrm{W}$ microelectrodes encased in polyimide implanted for 7 days. L: pre-implant; R: post-implant. Corrosion has occurred, indicated by a darkening, loss of volume, and a change in surface morphology [92].

\subsection{W Alloys in Medical Implants}

In cardiovascular medicine, permanently implanted bare-metal stents are used to restore luminal patency in patients with obstructive coronary lesions. A common stent platform alloy used is L605 cobalt-chromium alloy with $15 \% \mathrm{~W} \mathrm{wt} \%$ [93]. No corrosion or failure has been reported. 
In prosthodontics, $\mathrm{W}$ is used as a component of cobalt-chromium alloys, e.g. Wirobond® $\mathrm{C}$ (BEGO $\mathrm{GmbH}$, Bremen, Germany) is 5\% w/w, containing also Co (61\%), Cr (26\%), Mo (6\%) and small amounts of $\mathrm{Fe}, \mathrm{Ce} \& \mathrm{C}$ [94]. No corrosion or failure has been reported.

In orthopaedics, cobalt-based wrought alloy ASTM F90 is used for total joint replacement; its composition is Co-20Cr-15W-10Ni. W composition is $14-16 \%$ (wt\%) [95]. It is a popular orthopaedic alloy [96]. No corrosion or failure has been reported.

\section{Thin Film Tungsten}

As designers think about smaller implanted devices, they will consider using thin-film methods. At present we do not know of any medical implants with thin tungsten films. However, aqueous corrosion studies of tungsten thin films have been performed, and this will be briefly reviewed here.

It is not a safe assumption that metals will exhibit identical behaviour, including corrosion, in thin film as they do in bulk; differences in grain size and orientation, pinhole formation, pitting, porosity, and other phenomena exist between the two states [97, 98].

Most discussions in the literature regarding behaviour of $\mathrm{W}$ thin films in aqueous solutions are from the IC industry, and their attempts to remove their oxide layers from tungsten ohmic contacts and through vias using CMP (chemical mechanical polishing) [28, 29, 46, 99-102]. There is some relevance for the implant designer.

Kneer used LPCVD to deposit $0.8 \mu \mathrm{m}$ thin films of tungsten via $\mathrm{WF}_{6}$ reduction onto silicon substrates using a 50nm TiN adhesion layer. X-ray diffraction patterns were identical to that of W powder standards. In the absence of peroxide the values for $\mathrm{i}_{\text {corr }}$ in the $\mathrm{pH}$ range 2-9 were approximately $1 \mu \mathrm{A} / \mathrm{cm}^{2}$, corresponding to a dissolution rate of $0.01 \mathrm{~nm} / \mathrm{min}$ for tungsten dissolving to the hexavalent species. Unsurprisingly, peroxide solutions rapidly etched through the film, with complete dissolution in $10 \mathrm{~min}$ at $4-5 \%$ concentrations. FESEM micrographs depicted clear surface etching [46].

DC potentiodynamic polarization results indicate that in the absence of $\mathrm{H}_{2} \mathrm{O}_{2}$ an oxide layer forms which decreases tungsten dissolution in the $\mathrm{pH}$ range from 2 to 11 . This oxide layer provides the best passivation at $\mathrm{pH} 2$, less protection at $\mathrm{pH}$ from 4 to 9 , and none as the solution conditions become more alkaline [46]. This concurs with earlier bulk tungsten analysis.

Yin et al. provide data on the dissolution of thin film $\mathrm{W}$ oxides in deionized water, reporting dissolution rates of about $0.2-0.5 \mathrm{~nm} /$ day. Furthermore in the $\mathrm{pH}$ range of $7.4-8$ they report an order of magnitude higher dissolution rates $(\mu \mathrm{m} / \mathrm{hr}$ ) for physical deposition methods (sputtered) W compared to chemical (CVD W) in both DI $\left(4 \pm 1 \times 10^{-3}\right.$ vs $\left.7 \pm 2 \times 10^{-4}\right)$ and in Hank's solution $\left(8 \pm 2 \times 10^{-}\right.$ ${ }^{3}$ vs $7 \pm 2 \times 10^{-4}$ ) [97]. Given a typical $\mathrm{W}$ metallisation layer of $200 \mathrm{~nm}$ thickness, theoretically after $\sim 400$ days it would completely dissolve.

Some other issues for the implant designer to consider at thin film scales are electromigration, solid state diffusion, substrate adhesion and the effects of chronic implantation on solid state material properties. Tungsten reacts with silicon at $600^{\circ} \mathrm{C}$ (temperatures it reaches during physical vapour deposition methods) forming silicide compounds which will affect electrical properties - another consideration. 


\section{Toxicity of Tungsten}

In light of the previous corrosion analysis and with the knowledge that tungsten implants will invariably shed tungstates into the body, it is worth examining the data on its toxicity to inform future implant designers on its further use.

Concern for W toxicity began with epidemiological studies in Dayu County of Jianxi Province, China, where several $\mathrm{W}$ mines are located, which revealed breast cancer mortalities to be 13.8 times higher in men and 2.5 times higher in women compared to the national average (1985) [103]. Furthermore, childhood acute lymphocytic leukaemia (ALL) clusters were reported in Fallon, Nevada, US where CDC studies on toxicology and carcinogenesis showed elevated tungsten levels in drinking water and in the body burden in residents [104-107]. Further childhood ALL clusters were then reported in Sierra Vista, AZ and Elk Grove, CA, both of which were also rural desert towns in close proximity with tungsten mines, processing operations and military bases, with dendrochemistry consistently reporting significant increases in W compared to older wood [108, 109].

Acute tungsten intoxication was reported in a French soldier who had consumed $250 \mathrm{~mL}$ of wine though the barrel of a gun (inadvertently consuming $385 \mathrm{mg}$ of $\mathrm{W}$ used as a steel hardener). High concentrations of tungsten were measured in his serum, urine and stomach contents. Symptoms included seizure, loss of consciousness and tubular necrosis [110]. These reports were questioned by others who attributed the soldier's symptoms to 1,3,5-trinitro-1,3,5-triazine (also known as hexogen, cyclonite, or RDX) a military explosive compound and known epileptogenic, given the routine use of 25-80 g powdered tungsten metal by mouth as a substitute for barium in radiological examinations. This was rejected in turn [111]. Cell culture studies have been performed since, with the LD50 reported as being $50 \mathrm{mg} / \mathrm{ml}$ for human pulmonary arterial endothelial cells, $100 \mathrm{mg} / \mathrm{ml}$ for human pulmonary arterial smooth muscle cells and $1000 \mathrm{mg} / \mathrm{ml}$ for human dermal fibroblasts [73]. Another study reported markedly elevated tungsten concentrations in a culture medium of 120,000 times higher than baseline serum levels $(0.4 \mu \mathrm{g} / \mathrm{l})$ with in-vitro cultivation using human vascular endothelial cells, human fibroblasts, and human smooth muscle cells; no toxicity was reported [62]. Previous tungsten coil degradation studies in humans reported absence of toxicity resulting from corrosion in adult and paediatric patients despite elevated serum tungsten levels [16, 61, 67, 73, 74].

The role of W in heavy metal disease has also been explored; while W is thought of as a hard metal, it has been reported that the disease does not relate to the levels of $\mathrm{W}$ in blood, urine, pubic hair and toe nails [112]. Concentrations of tungsten in the blood, toenails, urine and pubic hair, is reported to be elevated even in asymptomatic workers exposed to tungsten dust as compared to normal subjects [113]. In similar data on other occupational exposures in plants with $\mathrm{W}$ powder metallurgy, workers chronically exposed to $\mathrm{W}$ air concentrations of $5 \mathrm{mg} / \mathrm{m}^{3}(0.7 \mathrm{ppm})$ developed no pneumoconiosis [104].

A synergistic toxicity with cobalt was first reported by Lison, with the combination more toxic towards murine macrophages than Co alone [114]. Similarly studies of military munitions of HMTAs (heavy metal tungsten alloys) consisting of $\mathrm{W}, \mathrm{Co}, \mathrm{Ni}$ and $\mathrm{Fe}$ showed the compounds to be genotoxic, inducing neoplastic transformation of human osteoblast cells to the tumorigenic phenotype [115]. Other studies on military rWNiCo (reconstituted) also show tumorigenic effects [116]. Kalinich performed similar studies whereby weapons-grade tungsten alloy $(91.1 \mathrm{~W}-6.0 \mathrm{Ni}-2.9 \mathrm{Co})$ embedded intramuscularly in F344 rats rapidly induced metastatic high-grade rhabdomyosarcomas [117]. 
Kalinich, as did Miller, argues that there exists a synergistic toxicity of W with other hard metals, and suggests this may have occurred environmentally at Fallon [106]. Others too have reported cytotoxicity of the W-Co combination [118].

As described earlier, these metal combinations (though in different proportions) are present in stents, prosthodontic and orthopaedic implants, such as ASTM F90 (Co-20Cr-15W-10Ni) [93-96]. No such carcinogenicity has been reported for these applications.

Various animal studies are available: the intraperitoneal (i.p.) LD50 value of tungsten metal powder in rats is reported to be $5 \mathrm{~g} / \mathrm{kg}(0.03 \mathrm{~mol} / \mathrm{kg})$ [104]. Others have reported for sodium tungstate the oral and i.v. LD50 values were 1928.4 and $61.0 \mathrm{mg} / \mathrm{kg}$, respectively, whereas in mice, the LD50 values were found to be 1904.1 and $107.1 \mathrm{mg} / \mathrm{kg}$ likewise [119]. These LD50 values indicate that tungsten has a rather low toxicity. Orally administered tungstate has been reported to correct hyperglycaemia in insulin and non-insulin dependent models of diabetes in rats and mice. Undesirable side effects were not observed, and there was no evidence of intolerance after prolonged use [120-125]. In rabbits a 30-fold increase in $\mathrm{W}$ serum concentration 4 months after implantation did not lead to any signs of clinical or histopathological toxicity [64].

There is small discussion on the effect of speciation on toxicity with variable animal studies suggesting that sodium metatungstate is significantly more toxic than sodium tungstate [126-128]; given the dominant presence of tungstate as the soluble species, it is of small relevance.

The literature is varied, and clear conclusions are difficult to draw. The interested should refer to deeper explorations [129-132]. 


\section{Conclusion}

The use of pure tungsten in chronic medical implants should be avoided. It has several properties that have made its use attractive and so it has a long history for implants in several medical fields. However, poor corrosion resistance of the pure metal in aqueous solutions makes it unsuitable for use in chronic devices. Unlike many other metals, tungsten neither maintains a noble metallic surface, nor does it form a protective passivation layer of tungsten oxide. At the body's $\mathrm{pH}$ of 7.4, the solid $\mathrm{WO}_{3}$ layer will hydrate, and dissolve away into the soluble hexavalent anion, $\mathrm{W}^{6+}$ or $\mathrm{WO}_{4}{ }^{2-}$. This conclusion does not refer to its use within implantable alloys.

Corrosion has been reported in-vitro in distilled water, in PBS, in peroxide-rich PBS, and in-vivo with embolisation coils and micro-needle neural probes. The associated emission of tungstate ions has been observed, and elevated blood serum levels have been measured in various animal studies, and in various human patients. Its toxicity too is currently under investigation, with some reports of acute poisoning, and also of long term genotoxicity; yet as these investigations continue it remains the case that its poor corrosion behaviour leading to implant failure is the primary reason for avoiding its use. Given the wide range of materials available to medical implant designers, the authors recommend alternative materials.

\section{Acknowledgement}

This work has been funded by the Wellcome Trust (contract ref: 102037/Z/13/Z) and EPSRC (grant ref: NS/A000026/1) as part of the CANDO Innovative Engineering for Health project.

\section{Declaration of Interest}

The authors confirm that there are no known conflicts of interest associated with this publication and there has been no significant financial support for this work that could have influenced its outcome. 


\section{Appendix}

\section{Medical Device Recalls}

An exploratory search for "TUNGSTEN" in the US FDA "Medical Device Recalls" database was hoped to reveal other implant failures. Three cases were found:

1. A Class I recall in 2011 (Z-1865-2011) [133] of Axxent FlexiShield Mini, a radiotherapy beam-blocker device made of a circular silicone rubber pad containing tungsten particulate. The pad is $12.7 \mathrm{~cm}$ in diameter and $0.1 \mathrm{~cm}(1 \mathrm{~mm})$ thick. Recall reason: "[The] product may shed particles identified as tungsten."

2. A Class II recall in 2015 (Z-0120-2016) [134] of Medtronic Pipeline Flex Embolisation Device. Made of $75 \%$ cobalt-chromium $/ 25 \%$ platinum-tungsten. Recall reason: "The firm is recalling Pipeline and Pipeline Flex Embolisation Devices from U.S. since the devices were shipped with an EU version of the Instructions for Use."

3. A Class II recall in 2010 (Z-1760-2010) [135] of Boston Scientific Back-Up Meier Steerable Guidewires, made of a stainless-steel, PTFE-coated proximal shaft, and a distal tip of radioopaque gold-plated tungsten spring coil wound around a stainless-steel inner core. Recall reason: "Through their internal inspection process, they identified that the polytetrafluoroethylene (PTFE) coating on the gold plated distal coil of the Back-up Meier Steerable Guidewires of the identified lots/batches have the potential for PTFE delamination."

Similarly, a search for "TUNGSTEN" in the Australian TGA "System for Australian Recall Actions" database reveals one case:

1. A Class II recall in 2015 (RC-2015-RN-00263-1) [136] or AngioDynamics Morpheus Smart PICC CT (central venous catheters); tungsten content unclear. Recall reason: "Based on a review of complaints, AngioDynamics has determined that the power injectable PICC catheters contained in these kits exhibit a higher than anticipated rate of extension tube fracture or leakage."

Similar searches in the UK MHRA "Alerts and Recalls for Drugs and Medical Devices" database [137] \& EU EMA "Product defects and recalls" database revealed no similar results.

None were corrosive in nature. 


\section{Bibliography}

1. Tietz, T.E. and J.W. Wilson, Behavior and properties of refractory metals. 1965: Stanford University Press.

2. Bauccio, M., ASM Metal Reference Book ASM International. Materials Park, USA, 1993.

3. Lassner, E. and W.D. Schubert, Tungsten: Properties, Chemistry, Technology of the Elements, Alloys, and Chemical Compounds. 1999: Springer US.

4. Lide, D.R., CRC Handbook of Chemistry and Physics, 85th Edition. 2004: Taylor \& Francis.

5. Koch-Bienemann, E., L. Berg, G. Czack, and G. Kirschstein, Gmelin Handbook of Inorganic Chemistry. W-Tungsten. Supplement Vol. A 3. Physical Properties (continued): Systemnumber 54. 1989: Springer.

6. Pettifor, D.G., Bonding and structure of molecules and solids. 1995: Oxford University Press.

7. Koch, E., W Tungsten: Supplement Volume A 7 Metal, Chemical Reactions with Inorganic and Organic Compounds. 8th Edition ed. Gmelin Handbook of Inorganic and Organometallic Chemistry - 8th edition. 2013: Springer Berlin Heidelberg.

8. McMaster, J. and J.H. Enemark, The active sites of molybdenum- and tungsten-containing enzymes. Current Opinion in Chemical Biology, 1998. 2(2): p. 201-207.

9. Johnson, M.K., D.C. Rees, and M.W. Adams, Tungstoenzymes. Chemical reviews, 1996. 96(7): p. 2817-2840.

10. Leggett, R.W., A model of the distribution and retention of tungsten in the human body. Science of The Total Environment, 1997. 206(2-3): p. 147-165.

11. Shreir, L.L., R. Jarman, and G. Burstein, Corrosion, vol. 1, Metal/environment reactions. Butterworth Heinemann, 1994. 4: p. 125.

12. Weisman, S., Metals for implantation in the human body. Annals of the New York Academy of Sciences, 1968. 146(1): p. 80-95.

13. Patrick, E., M.E. Orazem, J.C. Sanchez, and T. Nishida, Corrosion of tungsten microelectrodes used in neural recording applications. Journal of Neuroscience Methods, 2011. 198(2): p. 158-171.

14. Pourbaix, M., Electrochemical corrosion of metallic biomaterials. Biomaterials, 1984. 5(3): p. 122-134.

15. Laing, P., Clinical experience with prosthetic materials: Historical perspectives, current problems, and future directions, in Corrosion and Degradation of Implant Materials. 1979, ASTM International.

16. Weill, A., V. Ducros, C. Cognard, M. Piotin, and J. Moret, "Corrosion" of tungsten spirals. A disturbing finding. Interventional Neuroradiology, 1998. 4(4): p. 337-340.

17. Freire, M.A.M., E. Morya, J. Faber, J.R. Santos, J.S. Guimaraes, N.A. Lemos, K. Sameshima, A. Pereira, S. Ribeiro, and M.A. Nicolelis, Comprehensive analysis of tissue preservation and recording quality from chronic multielectrode implants. PLoS One, 2011. 6(11): p. e27554.

18. Heumann, T. and N. Stolica, The electrochemical behaviour of tungsten-I. The dissolution of tungsten and tungsten oxides in buffer solutions. Electrochimica Acta, 1971. 16(5): p. 643651.

19. Pourbaix, A. and M. Pourbaix, On the Corrosion, Immunity and Passivation of Tungsten and Molybdenum: Experimental Potential-pH Diagrams. 1984: Centre belge d'étude de la corrosion.

20. Pourbaix, M., Atlas of Electrochemical Equilibria in Aqueous Solutions. 1966: Pergamon Press.

21. Anik, M. and K. Osseo-Asare, Effect of pH on the anodic behavior of tungsten. Journal of The Electrochemical Society, 2002. 149(6): p. B224-B233.

22. Weidman, M.C., D.V. Esposito, I.J. Hsu, and J.G. Chen, Electrochemical stability of tungsten and tungsten monocarbide (WC) over wide $\mathrm{pH}$ and potential ranges. Journal of the Electrochemical Society, 2010. 157(12): p. F179-F188. 
23. Anik, M., Anodic reaction characteristics of tungsten in basic phosphate solutions. Corrosion Science, 2010. 52(9): p. 3109-3117.

24. Reichman, B., A.J. Bard, and D. Laser, A digital simulation model for electrochromic processes at WO 3 electrodes. Journal of The Electrochemical Society, 1980. 127(3): p. 647654.

25. Meulenkamp, E., Mechanism of WO 3 Electrodeposition from Peroxy-Tungstate Solution. Journal of the Electrochemical Society, 1997. 144(5): p. 1664-1671.

26. Butler, M., In situ photoemission from semiconducting WO3 electrodes. Surface Science, 1980. 101(1-3): p. 155-161.

27. Desilvestro, J., M. Grätzel, and T. Pajkossy, Electron Transfer at the WO 3-Electrolyte Interface under Controlled Mass Transfer Conditions. Journal of the Electrochemical Society, 1986. 133(2): p. 331-336.

28. Kaufman, F., D. Thompson, R. Broadie, M. Jaso, W. Guthrie, D. Pearson, and M. Small, Chemical-mechanical polishing for fabricating patterned $W$ metal features as chip interconnects. Journal of The Electrochemical Society, 1991. 138(11): p. 3460-3465.

29. Stein, D., D.L. Hetherington, and J.L. Cecchia, Investigation of the Kinetics of Tungsten Chemical Mechanical Polishing in Potassium Iodate-Based Slurries: I. Role of Alumina and Potassium lodate. Journal of the Electrochemical Society, 1999. 146(1): p. 376-381.

30. Anik, M., pH-dependent anodic reaction behavior of tungsten in acidic phosphate solutions. Electrochimica acta, 2009. 54(15): p. 3943-3951.

31. Ammar, I.A. and R. Salim, Anodic behaviour of tungsten-I. Oxidation kinetics in acid media. Corrosion Science, 1971. 11(8): p. 591-609.

32. Wiberg, E. and N. Wiberg, Inorganic Chemistry. 2001: Academic Press.

33. Johnson, J. and C. Wu, The anodic dissolution of tungsten. Journal of The Electrochemical Society, 1971. 118(12): p. 1909-1912.

34. Kelsey, G.S., The anodic oxidation of tungsten in aqueous base. Journal of the Electrochemical Society, 1977. 124(6): p. 814-819.

35. Olsson, C.-O., M.-G. Vergé, and D. Landolt, EQCM study of anodic film growth on valve metals. Journal of The Electrochemical Society, 2004. 151(12): p. B652-B660.

36. Heumann, T. and N. Stolica, The electrochemical behaviour of tungsten-II. The dissolution of tungsten in NaOH solutions. Electrochimica Acta, 1971. 16(10): p. 1635-1646.

37. Armstrong, R.D., K. Edmondson, and R.E. Firman, The anodic dissolution of tungsten in alkaline solution. Journal of Electroanalytical Chemistry and Interfacial Electrochemistry, 1972. 40(1): p. 19-28.

38. Davydov, A., V. Krylov, and G. Ehngel'gardt, Limit currents of electrochemical dissolution of tungsten and molybdenum in alkali. Ehlektrokhimiya, 1980. 16(2): p. 192-196.

39. El-Basiouny, M.S. and M.M. Hefny, Electrochemical Behaviour of Tungsten: II. Corrosion and anodic dissolution of tungsten in alkaline phosphate solutions. British Corrosion Journal, 1981. 16(1): p. 50-52.

40. Ortiz, P., M.L. Teijelo, and M. Giordano, Electrochemical behaviour of tungsten in alkaline media: Part I. NaOH solutions. Journal of electroanalytical chemistry and interfacial electrochemistry, 1988. 243(2): p. 379-391.

41. Ortiz, P., M. Giordano, and M.L. Teijelo, Electrochemical behaviour of tungsten in alkaline media: Part II. Sodium carbonate solutions. Journal of electroanalytical chemistry and interfacial electrochemistry, 1988. 251(2): p. 393-401.

42. El-Wakkad, S., H. Rizk, and I. Ebaid, The Electrochemical Behavior of the Tungsten Electrode and the Nature of the Different Oxides of the Metal. The Journal of Physical Chemistry, 1955. 59(10): p. 1004-1008. 
43. El-Basiouny, M.S., S.A. Hassan, and M.M. Hefny, On the electrochemical behaviour of tungsten: the formation and dissolution of tungsten oxide in sulphuric acid solutions. Corrosion Science, 1980. 20(7): p. 909-917.

44. Di Paola, A., F. Di Quarto, and G. Serravalle, A tensiostatic study of the anodic behaviour of tungsten in acid solutions. Journal of the Less Common Metals, 1975. 42(3): p. 315-324.

45. Charlot, G., L'analyse qualitative et les réactions en solutions. 4th ed. 1957, Paris: Masson.

46. Kneer, E.A., C. Raghunath, S. Raghavan, and J.S. Jeon, Electrochemistry of chemical vapor deposited tungsten films with relevance to chemical mechanical polishing. Journal of the Electrochemical Society, 1996. 143(12): p. 4095-4100.

47. Ganiev, S.U., T. Artykbaev, and G. Tsyganov, On the kinetics and products of molybdenum and tungsten dissolving in hydrogen peroxide. Zhurnal Neorganicheskoj Khimii, 1973. 18(3): p. 709-711.

48. Ganiev, S. and T. Artykbaev, Dissolution of Molybdenum and Tungsten in Hydrogen Peroxide Solutions. Freund Publishing House, Hydrometallurgy of Nonferrous and Rare Earths, 1980: p. 142-149.

49. Burke, B. and C.E. Lewis, The macrophage. 2002.

50. Paoletti, R., A. Notario, and G. Ricevuti, Phagocytes: biology, physiology, pathology, and pharmacotherapeutics. Vol. 832. 1997: New York Academy of Sciences.

51. Dahlgren, C. and A. Karlsson, Respiratory burst in human neutrophils. Journal of Immunological Methods, 1999. 232(1-2): p. 3-14.

52. Hampton, M.B., A.J. Kettle, and C.C. Winterbourn, Inside the neutrophil phagosome: oxidants, myeloperoxidase, and bacterial killing. Blood, 1998. 92(9): p. 3007-3017.

53. Chettibi, S., M. Ferguson, J. Gallin, and R. Snyderman, Wound repair: an overview. Inflammation: Basic principles and clinical correlates, 1999. 3: p. 865-881.

54. Prasad, A., Q.-S. Xue, V. Sankar, T. Nishida, G. Shaw, W.J. Streit, and J.C. Sanchez, Comprehensive characterization and failure modes of tungsten microwire arrays in chronic neural implants. Journal of neural engineering, 2012. 9(5): p. 056015.

55. El-Basiouny, M., F.E.-T. Heakel, and M. Hefny, On the Electrochemical Behavior of Tungsten: Corrosion Behavior of Tungsten in Buffer Solutions as Revealed by Potential and Impedance Measurements at Open Circuit. Corrosion, 1981. 37(3): p. 175-178.

56. Anik, M. and T. Cansizoglu, Dissolution kinetics of WO3 in acidic solutions. Journal of applied electrochemistry, 2006. 36(5): p. 603-608.

57. Anik, M., Effect of concentration gradient on the anodic behavior of tungsten. Corrosion Science, 2006. 48(12): p. 4158-4173.

58. Kim, T.S., J.H. Park, Y. Lee, J.W. Chung, and M.C. Han, An experimental study on thrombogenicity of various metallic microcoils with or without thrombogenic coatings. Investigative radiology, 1998. 33(7): p. 407-410.

59. Reul, J., J. Weis, U. Spetzger, T. Konert, C. Fricke, and A. Thron, Long-term angiographic and histopathologic findings in experimental aneurysms of the carotid bifurcation embolized with platinum and tungsten coils. American journal of neuroradiology, 1997. 18(1): p. 35-42.

60. Bachthaler, M., M. Lenhart, C. Paetzel, S. Feuerbach, J. Link, and C. Manke, Corrosion of tungsten coils after peripheral vascular embolization therapy: Influence on outcome and tungsten load. Catheterization and Cardiovascular Interventions, 2004. 62(3): p. 380-384.

61. Peuster, M., V. Kaese, G. Wuensch, P. Wuebbolt, M. Niemeyer, R. Boekenkamp, C. Fink, H. Haferkamp, and G. Hausdorf, Dissolution of tungsten coils leads to device failure after transcatheter embolisation of pathologic vessels. Heart, 2001. 85(6): p. 703-704.

62. Peuster, M., V. Kaese, G. Wuensch, C. von Schnakenburg, M. Niemeyer, C. Fink, H. Haferkamp, and G. Hausdorf, Composition and in vitro biocompatibility of corroding tungsten coils. Journal of Biomedical Materials Research Part B: Applied Biomaterials, 2003. 65B(1): p. 211-216. 
63. Reul, J., Editorial Comment - "Corrosion of Tungsten Spirals" by Weill et al. . Interventional Neuroradiology, 1998. 4(4): p. 341-342.

64. Peuster, M., C. Fink, P. Wohlsein, M. Bruegmann, A. Günther, V. Kaese, M. Niemeyer, H. Haferkamp, and C.v. Schnakenburg, Degradation of tungsten coils implanted into the subclavian artery of New Zealand white rabbits is not associated with local or systemic toxicity. Biomaterials, 2003. 24(3): p. 393-399.

65. Minoia, C., E. Sabbioni, P. Apostoli, R. Pietra, L. Pozzoli, M. Gallorini, G. Nicolaou, L. Alessio, and E. Capodaglio, Trace element reference values in tissues from inhabitants of the European Community I. A study of 46 elements in urine, blood and serum of Italian subjects. Science of the total environment, 1990. 95: p. 89-105.

66. Barrett, J., I. Wells, R. Riordan, and C. Roobottom, Endovascular embolization of varicoceles: resorption of tungsten coils in the spermatic vein. Cardiovascular and interventional radiology, 2000. 23(6): p. 457-459.

67. Butler, T.J., R.W. Jackson, J.Y. Robson, R.J. Owen, H.T. Delves, C.E. Sieniawska, and J.D. Rose, In vivo degradation of tungsten embolisation coils. The British Journal of Radiology, 2000. 73(870): p. 601-603.

68. Kampmann, C., R. Brzezinska, M. Abidini, A. Wenzel, C.-F. Wippermann, P. Habermehl, M. Knuf, and R. Schumacher, Biodegradation of tungsten embolisation coils used in children. Pediatric radiology, 2002. 32(12): p. 839-843.

69. Pelz, D., Potential hazards in the use of tungsten mechanical detachable coils. Radiology, 2000. 214(2): p. 602-603.

70. Lalak, N. and S. Moussa, 'Corrosion'of tungsten spirale coils in the genitourinary tract. Clinical radiology, 2002. 57(4): p. 305-308.

71. Ducros, V., A. Weill, and C. Cognard, Corrosion of Tungsten Spirals. Interventional Neuroradiology, 1999. 5(1): p. 81-82.

72. Ya-Suo, D. and L. Yu-Chang, Tungsten Coil Disappearance and SAH Recurrence 12 Years After Endovascular Embolisation. Clinical neuroradiology, 2014. 24(2): p. 189-191.

73. Peuster, M., C. Fink, and C. von Schnakenburg, Biocompatibility of corroding tungsten coils: in vitro assessment of degradation kinetics and cytotoxicity on human cells. Biomaterials, 2003. 24(22): p. 4057-4061.

74. Peuster, M., C. Fink, C. Von Schnakenburg, and G. Hausdorf, Dissolution of tungsten coils does not produce systemic toxicity, but leads to elevated levels of tungsten in the serum and recanalization of the previously occluded vessel. Cardiology in the Young, 2002. 12(03): p. 229-235.

75. Henze, D.A., Z. Borhegyi, J. Csicsvari, A. Mamiya, K.D. Harris, and G. Buzsáki, Intracellular features predicted by extracellular recordings in the hippocampus in vivo. Journal of neurophysiology, 2000. 84(1): p. 390-400.

76. Hubel, D.H., Tungsten microelectrode for recording from single units. Science, 1957. 125(3247): p. 549-550.

77. Geddes, L.A. and R. Roeder, Criteria for the Selection of Materials for Implanted Electrodes. Annals of Biomedical Engineering, 2003. 31(7): p. 879-890.

78. Anthony M. Dymond, Lloyd E. Kaechele, John M. Jurist, and Paul H. Crandall, Brain tissue reaction to some chronically implanted metals. Journal of Neurosurgery, 1970. 33(5): p. 574580.

79. Robinson, F.R. and M.T. Johnson, Histopathological Studies of Tissue Reactions to Various Metals Implanted in Cat Brains. 1961: Biomedical Laboratory, Aerospace Medical Laboratory, Aeronautical Systems Division, Air Force Systems Command, United States Air Force. 
80. Mills, L.W., A fast inexpensive method of producing large quantities of metallic microelectrodes. Electroencephalography and Clinical Neurophysiology, 1962. 14(2): p. 278279.

81. Grundfest, H., R.W. Sengstaken, W.H. Oettinger, and R.W. Gurry, Stainless Steel MicroNeedle Electrodes Made by Electrolytic Pointing. Review of Scientific Instruments, 1950. 21(4): p. 360-361.

82. Yuan, Y., L. Gang, J. Qinghui, and Z. Jianglong. A micromachine-based assembly of tungsten multichannel electrodes for neural recording. in $20083 \mathrm{rd}$ IEEE International Conference on Nano/Micro Engineered and Molecular Systems. 2008.

83. Sugiyama, K., W.K. Dong, and E.H. Chudler, A simplified method for manufacturing glassinsulated metal microelectrodes. Journal of neuroscience methods, 1994. 53(1): p. 73-80.

84. Merrill, E.G. and A. Ainsworth, Glass-coated platinum-plated tungsten microelectrodes. Medical and biological engineering, 1972. 10(5): p. 662-672.

85. Williams, J.C., R.L. Rennaker, and D.R. Kipke, Long-term neural recording characteristics of wire microelectrode arrays implanted in cerebral cortex. Brain Research Protocols, 1999. 4(3): p. 303-313.

86. Patrick, E., V. Sankar, W. Rowe, S.-F. Yen, J.C. Sanchez, and T. Nishida. Flexible polymer substrate and tungsten microelectrode array for an implantable neural recording system. in Engineering in Medicine and Biology Society, 2008. EMBS 2008. 30th Annual International Conference of the IEEE. 2008. IEEE.

87. Sanchez, J.C., N. Alba, T. Nishida, C. Batich, and P.R. Carney, Structural modifications in chronic microwire electrodes for cortical neuroprosthetics: a case study. IEEE Transactions on Neural Systems and Rehabilitation Engineering, 2006. 14(2): p. 217-221.

88. Carmena, J.M., M.A. Lebedev, R.E. Crist, J.E. O'Doherty, D.M. Santucci, D.F. Dimitrov, P.G. Patil, C.S. Henriquez, and M.A. Nicolelis, Learning to control a brain-machine interface for reaching and grasping by primates. PLoS biol, 2003. 1(2): p. e42.

89. Chapin, J.K., K.A. Moxon, R.S. Markowitz, and M.A. Nicolelis, Real-time control of a robot arm using simultaneously recorded neurons in the motor cortex. Nature neuroscience, 1999. 2(7): p. 664-670.

90. Williams, J.C., J.A. Hippensteel, J. Dilgen, W. Shain, and D.R. Kipke, Complex impedance spectroscopy for monitoring tissue responses to inserted neural implants. Journal of neural engineering, 2007. 4(4): p. 410.

91. Kralik, J.D., D.F. Dimitrov, D.J. Krupa, D.B. Katz, D. Cohen, and M.A. Nicolelis, Techniques for chronic, multisite neuronal ensemble recordings in behaving animals. Methods, 2001. 25(2): p. 121-150.

92. Streit, W.J., Q.S. Xue, A. Prasad, V. Sankar, E. Knott, A. Dyer, J.R. Reynolds, T. Nishida, G.P. Shaw, and J.C. Sanchez, Electrode Failure: Tissue, Electrical, and Material Responses. IEEE Pulse, 2012. 3(1): p. 30-33.

93. Garg, S., M. Magro, and P.W. Serruys, Drug-Eluting Stents, in Comprehensive Biomaterials: Biomaterials and Clinical Use, P. Ducheyne, et al., Editors. 2011, Elsevier Science. p. 431.

94. Naert, I., Materials in Fixed Prosthodontics for Indirect Dental Restorations, in Comprehensive Biomaterials: Biomaterials and Clinical Use, P. Ducheyne, et al., Editors. 2011, Elsevier Science. p. 360.

95. Kohn, D.H., Porous Coatings in Orthopaedics, in Comprehensive Biomaterials: Biomaterials and Clinical Use, P. Ducheyne, et al., Editors. 2011, Elsevier Science. p. 67.

96. Hallab, N.J. and J.J. Jacobs, Implant Debris: Clinical Data and Relevance, in Comprehensive Biomaterials: Biomaterials and Clinical Use, P. Ducheyne, et al., Editors. 2011, Elsevier Science. p. 105. 
97. Yin, L., H. Cheng, S. Mao, R. Haasch, Y. Liu, X. Xie, S.W. Hwang, H. Jain, S.K. Kang, and Y. Su, Dissolvable metals for transient electronics. Advanced Functional Materials, 2014. 24(5): p. 645-658.

98. Revie, R.W. and H.H. Uhlig, Uhlig's Corrosion Handbook. 2011: Wiley.

99. Stein, D.J., D. Hetherington, T. Guilinger, and J.L. Cecchi, In situ electrochemical investigation of tungsten electrochemical behavior during chemical mechanical polishing. Journal of The Electrochemical Society, 1998. 145(9): p. 3190-3196.

100. Kneer, E., C. Raghunath, V. Mathew, S. Raghavan, and J.S. Jeon, Electrochemical measurements during the chemical mechanical polishing of tungsten thin films. Journal of The Electrochemical Society, 1997. 144(9): p. 3041-3049.

101. Tamboli, D., S. Seal, V. Desai, and A. Maury, Studies on passivation behavior of tungsten in application to chemical mechanical polishing. Journal of Vacuum Science \& Technology A: Vacuum, Surfaces, and Films, 1999. 17(4): p. 1168-1173.

102. Osseo-Asare, K., M. Anik, and J. DeSimone, Chemical mechanical polishing of tungsten: effect of tungstate ion on the electrochemical behavior of tungsten. Electrochemical and solidstate letters, 1999. 2(3): p. 143-144.

103. Wei, H.-J., X.-M. Luo, and S.P. Yang, Effects of molybdenum and tungsten on mammary carcinogenesis in SD rats. Journal of the National Cancer Institute, 1985. 74(2): p. 469-473.

104. Haneke, K.E., B.L. Carson, C.A. Gregorio, A. Emanuel, and M.R. Wood, Tungsten and Selected Tungsten Compounds - Review of Toxicological Literature. 2003.

105. Sheppard, P. and M. Witten. Heavy metal content in airborne dust of childhood leukemia cluster areas: even small towns have air pollutants. in AGU Fall Meeting Abstracts. 2004.

106. Kalinich, J.F., Tungsten Alloy and Cancer in Rats: Kalinich Responds. Environmental Health Perspectives, 2005. 113(12): p. A802-A802.

107. Sheppard, P.R., G. Ridenour, R.J. Speakman, and M.L. Witten, Elevated tungsten and cobalt in airborne particulates in Fallon, Nevada: possible implications for the childhood leukemia cluster. Applied Geochemistry, 2006. 21(1): p. 152-165.

108. Sheppard, P. and M. Witten. Dendrochemistry of urban trees in an environmental exposure analysis of childhood leukemia cluster areas. in AGU Fall Meeting Abstracts. 2003.

109. Sheppard, P.R., R.J. Speakman, G. Ridenour, and M.L. Witten, Temporal variability of tungsten and cobalt in Fallon, Nevada. Environmental health perspectives, 2007: p. 715-719.

110. Marquet, P., B. Francois, P. Vignon, and G. Lachâtre, A soldier who had seizures after drinking quarter of a litre of wine. The Lancet, 1996. 348(9034): p. 1070.

111. Lison, D., J.P. Bucket, and P. Hoet, Toxicity of tungsten. The Lancet, 1997. 349(9044): p. 58.

112. Sabbioni, E., C. Minoia, R. Pietra, G. Mosconi, A. Forni, and G. Scansetti, Metal determinations in biological specimens of diseased and non-diseased hard metal workers. Science of the total environment, 1994. 150(1-3): p. 41-54.

113. Nicolaou, G., R. Pietra, E. Sabbioni, G. Mosconi, G. Cassina, and P. Seghizzi, Multielement determination of metals in biological specimens of hard metal workers: a study carried out by neutron activation analysis. Journal of trace elements and electrolytes in health and disease, 1987. 1(2): p. 73-77.

114. Lison, D. and R. Lauwerys, Study of the mechanism responsible for the elective toxicity of tungsten carbide-cobalt powder toward macrophages. Toxicology Letters, 1992. 60(2): p. 203-210.

115. Miller, A.C., S. Mog, L. McKinney, L. Luo, J. Allen, J. Xu, and N. Page, Neoplastic transformation of human osteoblast cells to the tumorigenic phenotype by heavy metaltungsten alloy particles: induction of genotoxic effects. Carcinogenesis, 2001. 22(1): p. 115125 . 
116. Miller, A.C., Potential late health effects of depleted uranium and tungsten used in armorpiercing munitions: comparison of neoplastic transformation and genotoxicity with the known carcinogen nickel. Military medicine, 2002. 167(2): p. 120.

117. Kalinich, J.F., C.A. Emond, T.K. Dalton, S.R. Mog, G.D. Coleman, J.E. Kordell, A.C. Miller, and D.E. McClain, Embedded Weapons-Grade Tungsten Alloy Shrapnel Rapidly Induces Metastatic High-Grade Rhabdomyosarcomas in F344 Rats. Environmental Health Perspectives, 2005. 113(6): p. 729-734.

118. Bastian, S., W. Busch, D. Kühnel, A. Springer, T. Meißner, R. Holke, S. Scholz, M. Iwe, W. Pompe, and M. Gelinsky, Toxicity of tungsten carbide and cobalt-doped tungsten carbide nanoparticles in mammalian cells in vitro. Environmental health perspectives, 2009. 117(4): p. 530.

119. Fernandez-Alvarez, J., J. Zapatero, and C. Piñol. Acute oral and intravenous toxicity of sodium tungstate: a potential agent to treat diabetes mellitus. in Symposium on The Insulinomimetic Effects of Metal Ions: Potential Therapy for Diabetes Mellitus, Sitges, Spain. 2000

120. Fillat, C., J. Rodriguez-Gil, and J. Guinovart, Molybdate and tungstate act like vanadate on glucose metabolism in isolated hepatocytes. Biochemical Journal, 1992. 282(3): p. 659-663.

121. Goto, Y., K. Kida, M. Ikeuchi, Y. Kaino, and H. Matsuda, Synergism in insulin-like effects of molybdate plus $\mathrm{H} 2 \mathrm{O} 2$ or tungstate plus $\mathrm{H} 2 \mathrm{O} 2$ on glucose transport by isolated rat adipocytes. Biochemical pharmacology, 1992. 44(1): p. 174-177.

122. Li, J., G. Elberg, D. Gefel, and Y. Shechter, Permolybdate and pertungstate--potent stimulators of insulin effects in rat adipocytes: mechanism of action. Biochemistry, 1995. 34(18): p. 6218-6225.

123. Barbera, A., R. Gomis, N. Prats, J. Rodriguez-Gil, M. Domingo, R. Gomis, and J. Guinovart, Tungstate is an effective antidiabetic agent in streptozotocin-induced diabetic rats: a longterm study. Diabetologia, 2001. 44(4): p. 507-513.

124. Muñoz, M.C., A. Barberà, J. Domínguez, J. Fernàndez-Alvarez, R. Gomis, and J.J. Guinovart, Effects of tungstate, a new potential oral antidiabetic agent, in zucker diabetic fatty rats. Diabetes, 2001. 50(1): p. 131-138.

125. Nomiya, K., H. Torii, T. Hasegawa, Y. Nemoto, K. Nomura, K. Hashino, M. Uchida, Y. Kato, K. Shimizu, and M. Oda, Insulin mimetic effect of a tungstate cluster. Effect of oral administration of homo-polyoxotungstates and vanadium-substituted polyoxotungstates on blood glucose level of STZ mice. Journal of Inorganic Biochemistry, 2001. 86: p. 657-667.

126. Strigul, N., C. Galdun, L. Vaccari, T. Ryan, W. Braida, and C. Christodoulatos, Influence of speciation on tungsten toxicity. Desalination, 2009. 248(1): p. 869-879.

127. Strigul, N., Does speciation matter for tungsten ecotoxicology? Ecotoxicology and Environmental Safety, 2010. 73(6): p. 1099-1113.

128. Strigul, N., A. Koutsospyros, and C. Christodoulatos, Tungsten speciation and toxicity: acute toxicity of mono-and poly-tungstates to fish. Ecotoxicology and environmental safety, 2010. 73(2): p. 164-171.

129. Jonas, W., G.B. van der Voet, T.I. Todorov, and J.A. Centeno, Metals and health: a clinical toxicological perspective on tungsten and review of the literature. Military medicine, 2007. 172(9): p. 1002.

130. Koutsospyros, A., W. Braida, C. Christodoulatos, D. Dermatas, and N. Strigul, A review of tungsten: From environmental obscurity to scrutiny. Journal of Hazardous Materials, 2006. 136(1): p. 1-19.

131. Keith, S., D.B. Moffett, Z.A. Rosemond, D.W. Wohlers, R.J. Amata, G.L. Diamond, and S.G. Swarts, Toxicological Profile for Tungsten. 2005.

132. Schell, J.D. and M.J. Pardus, Preliminary risk-based concentrations for tungsten in soil and drinking water. Land Contamination and Reclamation, 2009. 17(1): p. 179. 
133. U.S. Food and Drug Administration. Class 1 Device Recall Axxent Flexishield Mini (Z-18652011). 2011. [Accessed 06/03/2017]; Available from: http://www.accessdata.fda.gov/scripts/cdrh/cfdocs/cfRES/res.cfm?id=97687.

134. U.S. Food and Drug Administration. Class 2 Device Recall Pipeline and Pipeline Flex (Z0120-2016). 2015. [Accessed 06/03/2017]; Available from: https://www.accessdata.fda.gov/scripts/cdrh/cfdocs/cfRES/res.cfm?id=140075.

135. U.S. Food and Drug Administration. Class 2 Device Recall Boston Scientific, BackUp Meier Steerable Guidewires (Z-1760-2010). 2010. [Accessed 06/03/2017]; Available from: https://www.accessdata.fda.gov/scripts/cdrh/cfdocs/cfRES/res.cfm?id=91343.

136. Therapeutic Goods Administration (Australia). AngioDynamics Morpheus Smart PICC CT (central venous catheters) (RC-2015-RN-00263-1). 2015. [Accessed 06/03/2017]; Available from: http://apps.tga.gov.au/PROD/SARA/arn-detail.aspx?k=RC-2015-RN-00263-1.

137. UK Medicines and Healthcare Products Regulatory Agency. Results of search term: "Tungsten". [Accessed 06/03/2017]; Available from: https://www.gov.uk/drug-devicealerts?keywords=tungsten\&issued_date $\% 5 \mathrm{~B}$ from $\% 5 \mathrm{D}=\&$ issued_date $\% 5 \mathrm{Bto} \% 5 \mathrm{D}=$. 